\section{Almir Muhović ${ }^{1}$}

University Business Academy in Novi Sad,

Faculty of Applied Management,

Economics and Finance, Belgrade, Serbia

Jonel Subić ${ }^{2}$

Institute of Agricultural Economics, Belgrade, Serbia
ORIGINAL SCIENTIFIC ARTICLE

doi:10.5937/ekonomika1904021M

Received: November, 12. 2019.

Accepted: December, 09. 2019.

\title{
ANALYSIS AND IMPACT OF MAIN MACRO AND MICROECONOMIC FACTORS ON THE GROWTH OF NPL-S IN THE EMERGING FINANCIAL MARKETS
}

\begin{abstract}
Starting from contemporary theoretical and practical knowledge in the field of banking and contemporary financial theory, this paper investigates the impact of major macroeconomic and microeconomic factors on the growth rate of nonperforming loans. The theoretical views expressed have been tested in the financial markets of developing Western Balkan countries; Serbia, Montenegro and Bosnia and Herzegovina. The survey period covered the period 2000 to 2015.
\end{abstract}

Key words: Loans, Gross Domestic Product (GDP), Unemployment Rates, Inflation Rates, Return on Assets (ROA) and Return on Equity (ROE).

JEL classification: E65, G21, H81

\section{АНАЛИЗА И УТИЦАЈ ГЛАВНИХ МАКРО \\ И МИКРОЕКОНОМСКИХ ФАКТОРА НА РАСТ НПЛ-А НА ФИНАНСИЈСКИМ ТРЖИШТИМА У РАЗВОЈУ}

\begin{abstract}
Апстракт
Полазећи од савремених теоријских и практичних знаға из области банкарства и савремене теорије финансија, овај рад истражује утицај главних макроекономских и микроекономских фактора на стопу раста неквалитетних кредита. Изражена теоријска стајалишта тестирана су на финансијским тржиштима земала западног Балкана у развоју; Србија, Црна Гора и Босна и Хериеговина. Период истраживана обухватио је период од 2000 до 2015.
\end{abstract}

Кључне речи: Кредити, бруто домаћи производ (БДП), стопа незапослености, стопа инфлације, Принос нА средства (РОА) и принос на сопствени капитал (POE).

\footnotetext{
${ }^{1}$ amuhovic@gmail.com

${ }^{2}$ Ionel.s@iep.bg.ac.rs
} 


\section{Introduction}

Financial institutions play an important role in the development of every economy. Banks play a particularly important role in this process because economic growth requires an efficient and sound banking sector that provides macroeconomic stability. However, in the other side the banks face with a credit risk and as much the economy in one country is less developed there is higher credit risks for banks. Therefore, one of the main problems which are facing developing countries is instability of the financial and banking sector in particular, due to the credit risks which is defined as the risk that debtors will not be able to repay the loan within the terms and conditions under which they have borrowed. In the modern banking the process of approving the credits has become more complex than before. Technology of crediting begins with filing the credit request which is then processed with the goal to determine accurate height of the credit risk. Bank brings credit estimate based upon the information which are presented by the loan applicant, based upon his or her own data as well as based upon the appropriate outside information. After credit approval the bank not only does the technical business regarding the charging the loan payments and interests but also monitors all credits which are in operational function. (Zipovski, Lj., et.al. 2013). There are three common ways of solving the problem of non-performing loans and as presented by (Popović,K.,2018) in case the bank and the borrower cooperate and mutually agree on a way of solving problem in the interest of both parties. The most common is one of the three following ways:

- refinancing: the other bank takes over the borrower's loan, usually a bank with a higher risk appetite;

- rescheduling: extension of the loan maturity, which reduces the monthly repayment for the borrower; and

- restructuring: a significant change in some of the existing loan terms and conditions - e.g. introduction of a grace period and extension of loan maturity against additional collateral; write-off of all or part of (regular and/or default) interest against immediate repayment of the agreed loan amount; sale of a part of the borrower's assets after which the received funds are shared between the bank and the borrower. (Popović,K.,2018).

Banking sector in Serbia and in other countries is characterized as quite turbulent, with many changes and uncertainty, so a specific style of leadership is the need and not the choice. (Berber,N., et.al. 2019). Also, as of 1990 the banking sector in these countires recognized that poor environmental performance of its clients represent a threat to their business success and that their clients' risks are also those of banks risks as well. The transformation of environmental risk into credit risk can occur for the following reasons:

deterioration of customer liquidity due to changing consumer preferences as a result of striving to achieve sustainability and due to the decrease in the value of the collateral. (Kostadinović,I.,Radojičić, J., 2017)

In the process of overall economic reforms in the transition process in Serbia and other CEE countries, the key role was the reform of the banking sector, which was rated at the high-risk in the 1990s, with a number of accumulated problems such as: high indebtedness, un collectability of receivables, connectedness of persons, the largest debtors were at the same time were the owners of banks, the problem of 
undercapitalization, lack of central bank independences and poor regulation and control of banks, which contributed to a significant lack of confidence in the financial system in Serbia. (Ercegovac, D., et.al. 2019). Most countries of the former planned economies in the Central and Eastern Europe have entered and finished the process of economic reform in the past 25 years and thus deepen the integration with the global financial market. As a result, linkages among national financial markets gradually strengthened, and an integrated regional capital market was starting to emerge. A theoretical approach suggests that investors should be able to allocate their capital freely in a one-world market, thereby reducing arbitrage opportunities across countries. (Živkov,D., et.al. 2016).

In this paper, the focus was on analyzing the impact of the unemployment rate, the inflation rate and the growth rate of the Gross Domestic Product on the emergence and movement of NPL-s, from one side and return on assets, the return on total bank equity and the capital adequacy ration, on the other sides.

\section{Research methodology}

In accordance with the goals of this research, as well as formulated basic scientific hypotheses in the paper, qualitative and quantitative methodology was applied. The result of the applied research methodologies is to understand the subject matter of the research, through determining the structure of the relationship between the variables and their outcomes. Starting from contemporary theoretical and practical knowledge in the field of banking and contemporary financial theory, the influence of major macroeconomic and microeconomic factors on the growth rate of non-performing loans has been analyzed. The theoretical views expressed have been tested in the financial markets of developing European countries; Serbia, Montenegro and Bosnia and Herzegovina. The NPL analysys covered the from 2000 to 2015 year. Data were collected from the official website of the World Bank and the Bank for International Settlement. (https://www.bis.org)

Researching such complex issues requires the use of appropriate research methods - analysis, synthesis, induction and deduction. In the conceptual definition of non-performaning loans and the identification of relevant factors that determine its occurrence and the rate of movement, an analytical scientific method was used, which involves a detailed analysis of certain phenomena, effects, movements of selected indicators and their classification. The descriptive method was used to represent the theoretical underpinnings of banking, the concept of non-performing loans, and factors that influence the rate of movement of non-performing loans. The characteristics of the data series related to the NPL factors and the NPL rate in these countries were analyzed using various descriptive statistical and econometric methods and models for the correlation analysis and unit root tests.

Testing of the formulated hypotheses were carried out using various econometric methods, first of all least squares, random effect, fixed effect, ordinary least squares and two-stage ordinary least squares methods. The least squares method, as well as the fixed effect and random effect methods, were used to estimate the parameters of a static model that examines the impact of key macro and microeconomic variables, which are included in the model as regressors. 


\section{Discussion of research results}

Below Figure no. 1 shows an overview of the data collected for the reporting period between 2000 to 2015 years. NPL ranges from $2,9 \%$ to $24.10 \%$. The average value of the NPL is approximately $12,75 \%$, which emphasizes the need to pay more attention to credit policy in the region in the future. GDP shows both negative and positive values. In the observed period, the GDP rate in the region ranged from negative 3,12\% to positive 17 ,29\%. However, the average value of this indicator indicates that these countries achieved economic growth in the observed period.

The average value of the unemployment indicator is extremely high, indicating the problem of unemployment in this region. This unemployment rate is well above the unemployment rate in the European Union. In the observed period, inflation ranged from $-0.91 \%$ to as high as $95 \%$, which was recorded since the beginning of the observation period in Serbia. $\mathrm{BiH}$ and Montenegro were also faced with a negative inflation rate in the observed period.

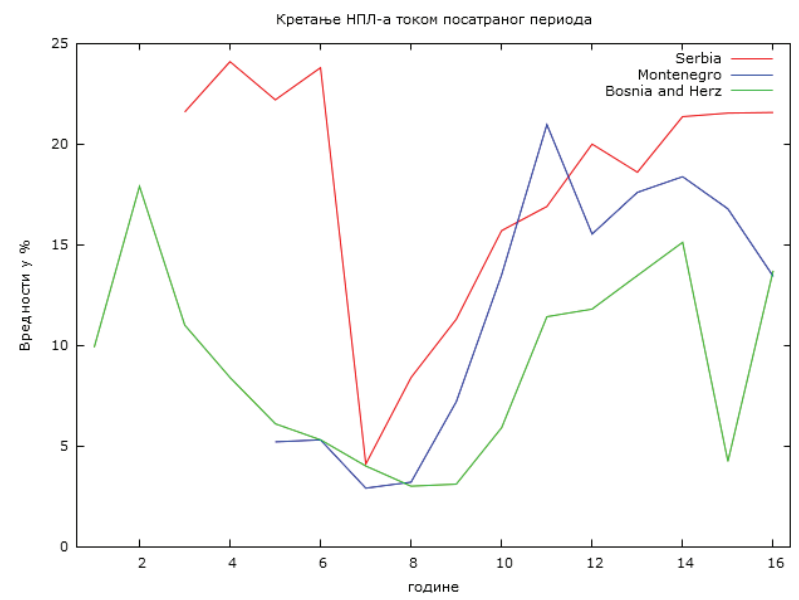

Figure no. 1. NPL movement over the observed period Source: Author

The high rate of standard deviation of macroeconomic variables can be interpreted, as a consequence of large fluctuations in economy and economic activities in these countries over the past fifteen years. This is particularly evident in the standard deviation of inflation, The ROA value illustrates the relatively low discrepancy between countries, although the minimum value reached a negative value of about $4.8 \%$.

This is primarily due to the negative and low profitability in Montenegro. On the other hand, although the average value of ROE, the discrepancy between countries is relatively large, which is a consequence of the negative profitability in Montenegro, more precisely the fact that for several years a significant number of banks recorded losses. Despite the various prudential requirements and standards prescribed by central banks, the high average CAR value is encouraging and indicates the resilience of the banking sector to extreme shocks and macroeconomic instability.

On the other hand, the relatively high standard deviation value of this parameter may also be an indication of changes in prudential requirements over the period under this 
review. Statistically significant variables are unemployment rate, ROA and CAR. A statistically significant and negative relationship was found between the unemployment rate and the NPL. More specifically, the results show that a $1 \%$ rise in unemployment results in a NPL drop of about 0,19 percent. This can be explained by the fact that people who lose their jobs do not take loans or that the bank does not issue loans to such people. The reason is also found in the fact that in these countries there are mechanisms for securing credit in the case of a debtor's joblessness.

It was also found that there was a negative and significant relationship between the growth of ROA and NPL. An increase in ROA of $1 \%$ leads to a decrease in NPL of about $2 \%$, as well as a positive relationship between CAR and NPL. Such findings are reported in the literature and are explained by the fact that banks with larger CARs enter into riskier credit arrangements and thus make riskier loan portfolios, which is reflected in the emergence of the NPL as well as its growth. The surprising result is that the NPL from the previous period does not affect the movement of the current NPL. Also, in this case the results of the assessment show that the inflation rate has no effect on the NPL.

This paper analysed the influence of the main macroeconomic and microeconomic factors on the growth rate of non-performing loans during the observed period and during the observed period we obtained the following trends shown in the below Figures no. 2, 3,4,5,6 and 7.

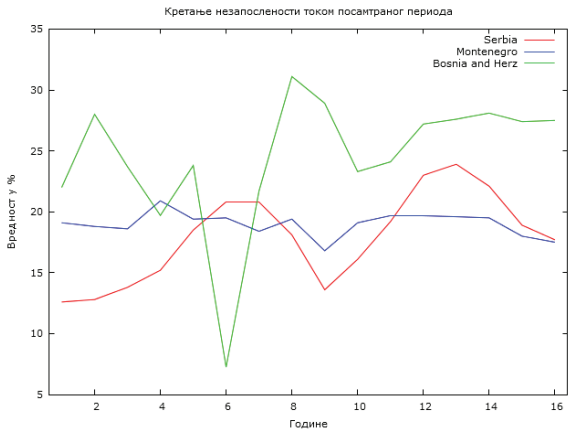

Figure no. 2. UNR movement during the observed period Source: Author

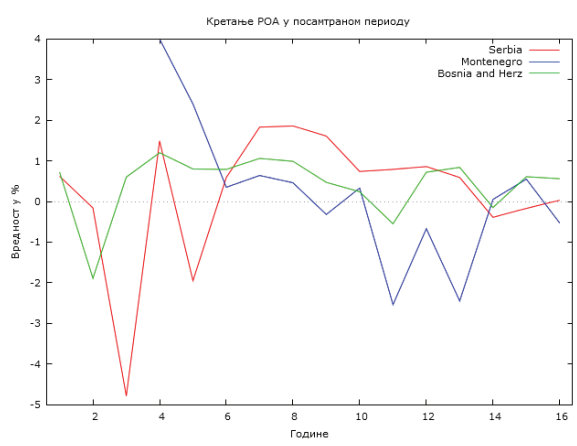

Figure no. 4. ROA movement during the observed period Source: Author

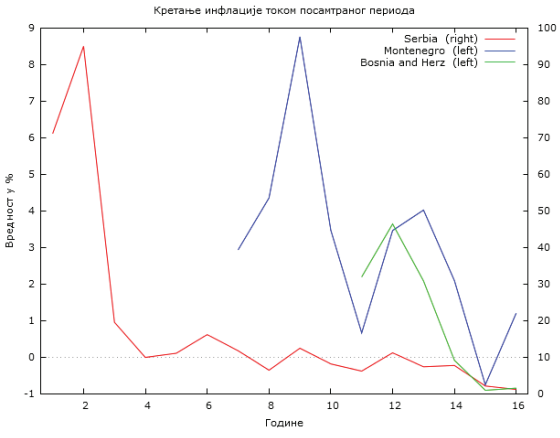

Figure no. 3 INF movement during the observed period Source: Author

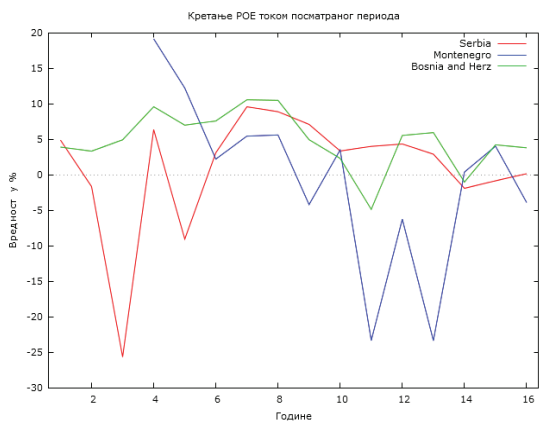

Figure no. 5. ROE movement during the observed period Source: Author 


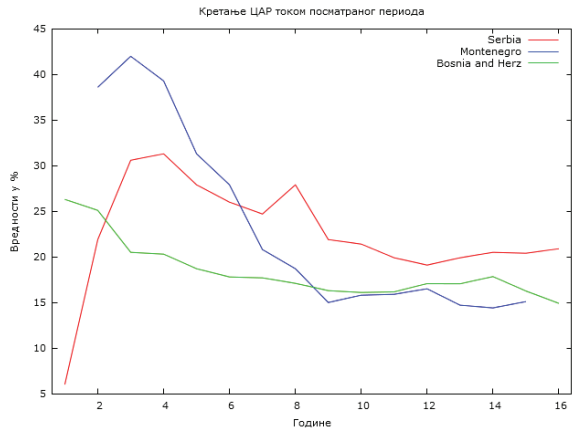

Figure no. 6. CAR movement during the observed period Source: Author

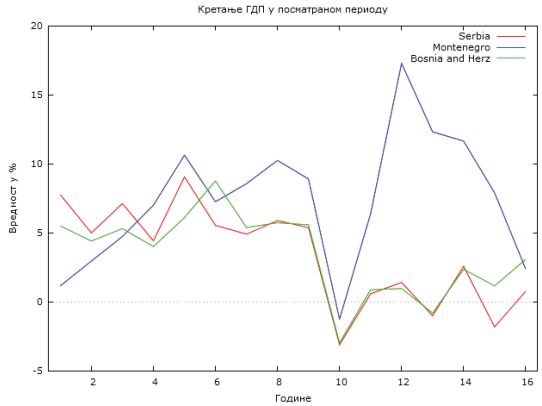

Figure no. 7. GDP trends over the observed period

Source: Author

And at the end, if we enforce a comparative analysis of the share of NPL to total loans in all three countries, it can be concluded that the share of NPL to total loans has Serbia with the participation of over $20 \%$ in 2016 year, as illustrated into the graph 1 :

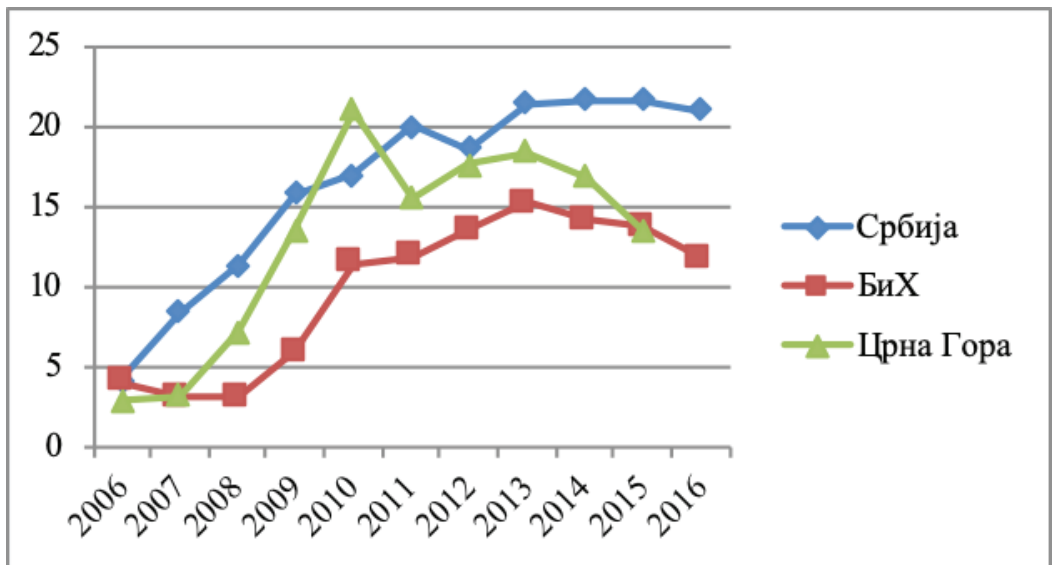

Graph 1. Comparative analysis of the share (\%) of NPLs in total loans of banks in Serbia, BiH and Montenegro. Source: World Bank

Based on the presented data shown in Figure 1, it can be concluded that there are conflicting interpretations of the obtained results that can lead to conflicting conclusions regarding the influence and significance of certain macro and micro variables on the NPL rate, and thus on the acceptance or rejection of the hypotheses set in this paper here. Therefore, drawing conclusions about the significance and type of relationship requires caution and consideration of all the results and characteristics of the model, as well as the various tests that speak in favor of the validity of the selected models.

Bearing in mind the above, conclusions are made below in the context of the obtained results of species testing and the significance of the relationships between the selected variables and the NPL. 
The research results brought us to the following:

1) that there is a negative and statistically significant relationship between unemployment and the NPL rate. This finding contradicts the view that unemployment reduces household disposable income and impairs the borrower's ability to pay its loan installments. This result contradicts the findings presented by Nkusu (2011), Louzis et al. (2012), Makri (2014) and others. This can be explained by the fact that people who lose their jobs do not take loans or that the bank does not issue loans to such people. This is also due to the fact that in these countries there are mechanisms for securing credit in the event of a debtor's joblessness;

2) to achieve a negative and significant relationship between gross domestic product and the NPL rate. This finding indicates that macroeconomic fluctuations are rapidly being transferred to the problem of bank lending in emigrating countries. Including the lagging GDP in the model, it can be concluded whether the impact of current GDP on the NPL is higher or lower compared to the lagged GDP. However, this is not the subject of the paper. Such a finding is consistent with the prevailing theoretical views;

3 ) that there is a negative and significant correlation between the inflation rate and the NPL rate. This result indicates that inflation in selected developing countries has a positive effect on the quality of banks' assets. This finding suggests that the effect of higher interest rates due to inflation and declining economic conditions, which are usually associated with rising inflation, do not outweigh the positive impact that inflation can have on a borrower's debt servicing capacity. This conclusion is in contrast to Mileris (2012) and Nkusu (2011), but is consistent with Tabak (2012), who also showed that there is a negative relationship between inflation and the NPL rate;

4) that there are negative and significant relationships between ROA and NPL rates. This result is consistent with the prevailing theoretical view that mismanagement leads to risky activities and poor performance. Radivojevic and Jovovic (2017) have presented this result in their research as well as many other authors such as Dimitrios (2012) who points out that this is in fact an examination of the "mismanagement" hypothesis. According to him, that efficiency based on low cost is positively associated with an increase in the rate of future NPLs. "Mismanagement" with poor credit rating skills, collateral valuation, and lender monitoring can lead to higher levels of NPLs. These results are in line with the studies of Radivojević and Jovović (2017), Gdlevski (2004), Stakić et al. but contrary to the findings of Garcia and Fernandez (2007), who point out that the increase in returns on bank eqity, is accompanied by the growth of NPLs. This negative link is also consistent with the argument that mismanagement leads to risky activities and poor performance.

5) that there are negative and significant relationships between CAR and NPL rates. This finding is against the attitude of banks towards risk-taking activities in cases of favorable capital adequacy. High CAR banks are involved in high risk activities, creating risky loan portfolios and thus high NPL rates. Encouraged by the prospect of higher profits, banks conscientiously engage in risky activities while raising the level of capital adequacy well above the prescribed minimum. This means that their lending activities also targeted smaller debtors of solvency. 


\section{Conclusion}

The dependent variable during this research process was the rate of Non performing Loan NPL), which is the sum of borrowed money which by definition means that the borrower is unable to repay the loan within more than 90 days from the due date for payment. Gross Domestic Product (GDP), Unemployment Rate (UNR), and Inflation Rate (INF) and Return on Equity (ROE), Return on Assets (ROA), and Capital Adequacy Rate (CAP) between Capital and Assets (CAR)) are used by me as explanatory variables. However, in this paper, these types of variables were used in one model for all three countries.

Empirical research shows that NPLs are closely linked to the economic and business cycles, ie. behind each financial crisis, there are macroeconomic factors, such as falls in aggregate economic activity. When growth slows or becomes negative, borrowers reduce their cash inflows, making it difficult for them to pay interest and principal. Under these circumstances, borrowers will face a lack of liquidity and delays in meeting their financial obligations to banks are likely to increase. Hence, GDP was used as a proxy for aggregate economic activity, as it is very informative about other relevant macroeconomic variables. For labor research purposes , the GDP variable has been converted to a logarithmic function and represents GDP growth over the years. GDP growth is expected to lead to a decrease in the NPL rate.

The inflation rate is also a significant indicator of the macroeconomic situation of an economy and is one of the biggest problems of central banks in many developing countries. In conditions of inflation, households face difficulties in repaying loans because as a rule prices rise faster than their income. Therefore, in the context of rising inflation it is expected that there will be an increase in the NPL rate. However, there are studies that indicate the opposite relationship between. In theory, inflation should reduce the real value of debt and thus facilitate debt service (Skarica, 2013).

When it comes to selected variables, the main criterion for their choice, in addition to their availability of data and their relevance to bank operations, was that there are conflicting conclusions in the literature regarding their effect on rates. For example, some authors such as Godlevsky (2004) and Stakic (2014), ROA and ROE show a significant and negative relationship between these variables and NPL. In other words, their findings show that banks with high efficiency (ROA) and high rate of profitability (ROE) have less pressure to make profits and thus less dependence on investing in risk-bearing placements and thus a lower NPL- a. At the same time, banks with low levels of profitability have more problems with high rates of NPL. However, research by Garsia and Fernandez (2007) suggests the opposite. Banks that had high rates of ROA and ROE were at higher risk and thus faced a higher NPL rate. A similar turn was reached by Boudrig and colleagues (2009). They identified a positive correlation between the variables mentioned and the NPL.

\section{References}

Berber,N., et.al. ( 2019), "A Survey on Relationship between Leadership Styles and Leadership Outcomes in the Banking Sector in Serbia“, Acta Polytechnica Hungarica, Vol. 16, No. 7, pp. 167 - 184. 
Garciya-Marco, T., Robles-Fernandez, M.D. (2007), „Risk taking behavior and ownership in the banking industry: The Spanish evidence", Journal of Economics and Business, Vol. 60, no. 4, 2007, pp. 332-354.

Kostadinović,I.,Radojičić, J., (2017), "Banking sector in the context of sustainable development”, Economics of sustainable Development, Vol. 1, No.2, pp 109-119.

Louzis, P. D., Vouldis, A. T., Metaxas, V. L. (2012), "Macroeconomic and bankspecific determinants of non-performing loans in Greece: A comparative study of mortgage, business and consumer loan portfolios." Journal of Banking and Finance, Vol. 36, No. 1, pp. 1012-1027.

Monetary Developments (2016), Central Bank of Montenegro, Macroeconomic Report 2016 pp . 52;

Makri, V., Tsagkanos, A., Bellas, A. (2014), “Determinants of Non-Performing Loans: The Case of Eurozone“. Panoeconomicus, No. 2, pp. 193-206.

Makri, V., Papadatos, K. (2012), "How accounting information and macroeconomic environment determine credit risk, Evidence from Greece. International Journal of Economic Sciences and Applied Research, Vol. 7, No. 1, pp. 129-143.

Muhović, A. et.al. (2018), "Empirical research determinant of NPL in emerging markets by using the fixed effects method: Study of the case of Serbia, Montenegro and Bosnia and Herzegovina, Vojno delo, No. 7., pp. 335 - 344.

Mileris, R. (2014), "Macroeconomic factors of non-performing loans in commercial banks“, Ekonomika, 2014, Vol. 93(1), pp. 22-39.

Nkusu, M.(2011), "Nonperforming Loans and Macrofinancial ulnerabilities in Advanced Economies."IMF Working Paper 161.

Програм еконосмких реформи за Црну Гору 2017-2019, стр. 20;

Radivojevic, N., et. al. (2019), „Econometric model of non-performing loans determinants", Physica A: Statistical Mechanics and its Applications, Vol. 520, April, pp. 481-488.

Radivojevic, N., Jovovic, J., (2017), „Examining of determinants of non-performing loans", Prague economic paper, Vol. 26, No. 3, pp. 300-316.

Skarica, B. (2013), "Determinants of Non-Performing Loans in Central and Eastern European Countries", Working Paper.

Tabak, B. et al. (2005), “The Stability-Concentration Relationship in the Brazilian Banking System.” The Banco Central do Brazil Working Papers, 145.

Vučinić, M. (2014), Financial Stability - Comparative Analysis: Montenegro, Serbia and the Netherlands, Journal of Central Banking Theory and Practice, 2015, 1, pp. 63-93.

Cvejić, A., (2016)," Effects of Nonperforming Placements on Equity and Capital Adequacy of Commercial Banks", Andrejevic Endowment, Belgrade, pp. 13

Cvejić, A., (2016), "Effects of Nonperforming Placements on Equity and Capital Adequacy of Commercial Banks", Andrejevic Endowment, Belgrade, pp. 19

Ercegovac, D., et.al. (2019)," The analysis of the key indicators of the Republic of Serbia banking sector",Anali Ekonomskog fakulteta u Subotici, Vol. 55, No. 41/2019, pp. 081-094. 
Simonović,Z., Jeločnik, M., \&Subić, J. (2013). Tax policy in Serbian agriculture. Ekonomika poljoprivrede, 60(3), 637-651.

Stakić, N., (2014), "Determinants of trends in the level of non-performing loans in the banking sector in Serbia. Bankarstvo, No. 4. pp. 122 -146.

Jovovic, J. (2014), "Determinants of Non-Performing Loans: Econometric Evidence Based on 25 Countries." Master thesis, City University, London.

Muhović, (2018), "Analysis of the factors of occurrence and movement of the level of nonperforming loans in the financial markets in development", Doctoral thesis, Faculty of Applied Management, Economics and Finace, Belgrade.

Methodology for Developing IRP and NPL Forms 1-5, National Bank of Serbia, p. 4, available at: https://www.nbs.rs/internet/cirilica/55/metodologija/index.html , (accessed: 01/09/2018).

National Bank of Serbia, Banking Sector of Serbia 3rd Quarter 2017, p. 15, available at: https://www.nbs.rs/internet/latinica/55/55_4/index.html , (accessed on: $01 / 15 / 2018)$

Popović,K.,(2018)," Rešavanje problematičnih kredita“, Bankarstvo , 2018, vol. 47, No. 3, pp 76-86.

Vučković, B., Veselinović, B., \& Drobnjaković, M. (2017). Financing of permanent working capital in agriculture. Ekonomika poljoprivrede, 64(3), 1065-1080.

World Bank, available at: https://data.worldbank.org/indicator/FB.AST.NPER.ZS?end $=2016 \&$ locations $=$ BA\&start $=2006 \& v i e w=$ chart, $($ accessed on: 01/06/2018).

Zipovski, Lj., et.al. (2013)," Credit Activities of Commercial Banks In Serbia: Causes And Consequences", Faculty of Business Economics and Entrepreneurship, International Review, (2013 No.3-4),pp 41-54.

Živkov,D., et.al. (2016)," Exchange Rate Volatility and Uncovered Interest Rate Parity in the European Emerging Economies", Prague Economic Papers, Vol. 25 , No. 3, pep. 562 